\title{
Viability and susceptibility of propagation material from coffee plants to Colletotrichum sp.
}

\section{Viabilidade e suscetibilidade de material propagativo de cafeeiro a Colletotrichum sp.}

\author{
Cláudio Ogoshi ${ }^{1}$; Felipe Augusto Moretti Ferreira Pinto ${ }^{2}$; Helon Santos Neto²; \\ Bruno Marques da Silva ${ }^{3}$; Mario Sobral de Abreu ${ }^{4 *}$; Mário Lúcio Vilela de Resende ${ }^{5}$
}

\begin{abstract}
This study aimed to verify the viability of propagation material from coffee plants descended from germplasm susceptible to blister spot disease as well as its susceptibility to Colletotrichum sp. relative to commercial coffee cultivars. In the first experiment, fruits were harvested from plants with and without symptoms of blister spot and sowed in trays containing a commercial sterilized substrate. The percentages of germinated seeds, viable plantlets and seedlings were evaluated. In diseased tissues, pathogens were isolated and identified though a pathogenicity test. In the second experiment, ten commercial cultivars and one cultivar originating from plants with blister spot were inoculated with the pathogens to assess the severity of anthracnose. Significant differences were not observed with respect to seed germination. However, the viability of plantlets and seedlings was reduced in the cultivar originating from plants with blister spot (Genotype Originated from Diseased Plants-GODP). These plants showed characteristic symptoms of blister spot, including necrosis in the leaves and hypocotyls, wilting and death. In the necrotic lesions, we observed characteristic sporulation of Colletotrichum sp. The cultivar most susceptible to anthracnose in cotyledonary leaves was Catuaí Vermelho (GODP), which presented the highest area under the disease progress curve (AUDPC). In conclusion, the viability of propagation material from coffee plants that had descended from plants with symptoms of blister spot (GODP) was reduced compared with plants from other genotypes, although seed germination was not affected. Moreover, GODP species are more susceptible to Anthracnose on the cotyledonary leaves relative to the other analyzed commercial cultivars. This work is the first to report on different symptoms exhibited by seedlings originating from the seeds of plants with symptoms of blister spot.

Key words: Anthracnose, Coffea arabica L, Genotype Originated from Diseased Plants (GODP), blister spot
\end{abstract}

\section{Resumo}

Objetivou-se neste trabalho verificar a viabilidade de material propagativo de cafeeiro proveniente de germoplasma susceptível a Mancha manteigosa, assim como a sua susceptibilidade a Colletotrichum sp. em comparação a cultivares comerciais de cafeeiro. No primeiro experimento, frutos foram colhidos de plantas com e sem sintomas da mancha manteigosa e a semeadura realizada em bandejas

1 Dr. em Fitopatologia, Dept ${ }^{\circ}$ Fitopatologia, Universidade Federal de Lavras, UFLA, Lavras, MG, Brasil. E-mail: claudiogoshi@ yahoo.com.br

2 Discentes do Curso de Doutorado em Fitopatologia, Dept ${ }^{\circ}$ de Fitopatologia, UFLA, Lavras, MG, Brasil. E-mail: felipemoretti113@, hotmail.com; helonareado@hotmail.com

3 Técnico Laboratório de Diagnose, Dept ${ }^{\circ}$ de Fitopatologia, UFLA, Lavras, MG, Brasil. E-mail: brunomarquesbio@hotmail.com

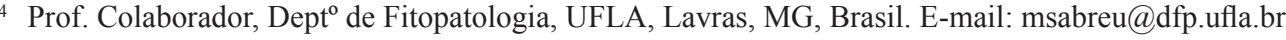

5 Prof. Titular, Dept ${ }^{\circ}$ de Fitopatologia, UFLA, Lavras, MG, Brasil. E-mail: mlucio@dfp.ufla.br

Author for correspondence 
contendo substrato esterilizado. Avaliou-se a porcentagem de sementes germinadas e de plântulas e mudas viáveis. Realizou-se o isolamento, a identificação do patógeno dos tecidos doentes e o teste de patogenicidade. No segundo experimento, inoculou-se o patógeno em dez cultivares de cafeeiro e em uma cultivar originada de plantas com Mancha manteigosa (GOPD) para a avaliação da severidade da antracnose. Não houve diferença quanto à germinação das sementes. Porém, a viabilidade das plântulas e das mudas, foi reduzida nos GOPDs. Estes apresentaram sintomas da mancha manteigosa, necrose nas folhas e nos hipocótilos, murcha e morte. Nas lesões necrosadas observou-se esporulação característica de Colletotrichum spp. A cultivar Catuaí Vermelho (GOPD) foi altamente suscetível à antracnose nas folhas cotiledonares apresentando a maior AACPD em relação aos outros genótipos testados. Concluise que a viabilidade de material propagativo de cafeeiro proveniente de sementes de plantas com Mancha manteigosa (GOPDs) é menor do que em plantas provenientes de outros genótipos, porém a germinação não foi afetada. Além disso, Os GOPDs são mais suscetíveis à Antracnose nas folhas cotiledonares do que em outras cultivares comerciais analisadas. Este trabalho foi o primeiro a relatar os diferentes sintomas apresentados pelas mudas originadas de sementes de plantas com sintomas da mancha manteigosa.

Palavras-chave: Antracnose, Coffea arabica L, Genótipo Originado de Plantas Doentes - GOPD, mancha manteigosa

\section{Introduction}

Coffee is a valuable and sought-after beverage and one of the main agricultural commodities in the world. Brazil is the biggest producer and exporter of coffee and had an estimated production of between 46.5 and 50.1 million bags $(60 \mathrm{~kg})$ of coffee in 2014. (COMPANHIA NACIONAL DE ABASTECIMENTO - CONAB, 2014). The state of Minas Gerais is responsible for more than half of the national production of coffee, and coffee is the main source of income for many municipalities.

Historically, plant health problems have impaired coffee culture from the nursery to production. These problems include fungal diseases such as Rust (Hemileia vastatrix), Brown eye spot (Cercospora coffeicola), Phoma spot (Phoma spp.), and diseases related to Colletotrichum complex, including Anthracnose, blister spot and Coffee Berry Disease (CBD). Recent studies have shown that CBD is not present in Brazil and restricted to the African continent (OROZCO-MIRANDA, 2003; BRIDGE et al., 2008; NGUYEN et al., 2009). CBD is a harmful disease to coffee and can cause losses of up to $80 \%$ when appropriate management measures are not applied (SILVA et al., 2012).

In Brazil, reports of Colletotrichum complex diseases are associated with anthracnose on branches, fruits and leaves, dieback and blister spot (PARADELA FILHO et al., 2001; OROZCOMIRANDA, 2003). The etiology of the diseases has been attributed to the species Colletotrichum gloeosporioides, which is found in all organs of coffee plants exhibiting foliar symptoms of the disease (OROZCO-MIRANDA, 2003; LINS et al., 2007; MARQUES, 2009; FERREIRA et al., 2009; PEREIRA et al., 2009). According to Paradela Filho et al. (2001), the most critical and damaging injuries from Anthracnose in coffee plants are those in which the fungus localizes on the buds, flowers and small green berries, which die and fall, and causes blackening and death of branches.

However, several authors have noted that the initial symptoms of blister spot occur in new leaves and appear as bright green oily patches that are less bright than the surface of the leaf and measure 2 to $10 \mathrm{~mm}$ in diameter. In advanced stages, the spots feature pale green or yellow colors and jagged edges. Finally, the spots coalesce, and premature leaf fall is observed (VARGAS; GONZÁLES, 1972; MANSK; MATIELLO, 1977; OROZCOMIRANDA, 2003; FERREIRA, 2006). Intense attacks of blister spot are observed in the leaves and young branches of adult plants, with necrosis and dry branches occurring at the apex and potentially causing plant death in descending form (FERREIRA et al., 2009). 
The interaction between Colletotrichum sp. and coffee plantlets is highly variable and depends on the susceptibility of the genetic material, genetic variability of the isolates and time from inoculation to the expression of symptoms (ABREU et al., 2008). Marques (2009) studied the pathogenicity of Colletotrichum isolates on the green fruit of coffee plants and identified variations in anthracnose symptoms between different coffee cultivars, with IAPAR 59 showing greater resistance among the observed plants. Sera et al. (2005a) reported that genotypes such as Obatã IAC 1669-20, Catucaí Vermelho 4-79 and IAPAR III-1-9 showed a low incidence of necrosis of the fruits, and the authors noted that this resistance resulted from the prior genetic crossing of Coffea canephora species because these cultivars contained genes of $C$. canephora.

Furthermore, plantlets originating from seeds harvested from plants with foliar symptoms of blister spot have been reported to be more susceptible to the disease, which can be transmitted by infected seeds (OROZCO-MIRANDA, 2003; FERREIRA et al., 2010; MAIA et al., 2013). Therefore, the aim of this study was to assess the viability of coffee plant propagation material derived from germplasm susceptible to blister spot as well as the material's susceptibility to Colletotrichum sp. compared with that of commercial cultivars of coffee.

\section{Material and Methods}

Experiment I - Seed germination and plantlet and seedling viability derived from the seeds of plants with blister spot symptoms

Collecting fruit, obtaining seeds and seedling production

Berries from the cultivar Catuaí Vermelho IAC 144 were harvested during the cherry stage from plants with and without blister spot symptoms, with the cultivar produced from the 2011/2012 crop of the Laje Farm, which is located in the municipality of Paraguaçu, Minas Gerais at the geographic coordinates $21^{\circ} 29^{\prime} 46.62^{\prime \prime} \mathrm{S} 45^{\circ} 46^{\prime} 13.14^{\prime \prime} \mathrm{W}$.

The berries were subjected to pulping to obtain the seeds. From these seeds, the mucilage was extracted by fermenting the seeds in water for 24 hours, washing in water, and then placing them in the shade to dry until $18 \%$ humidity was achieved. Sowing was performed in polystyrene trays with 120 cells containing commercial substrate sterilized by autoclaving. These trays were then transported to the greenhouse located in the Plant Pathology Department of the Federal University of Lavras, Lavras, Minas Gerais.

\section{Seed germination and plantlet viability}

The treatments consisted of seeds from plants with and without blister spot symptoms. The experiment was conducted using a randomized block design with five replicates and an experimental unit consisting of a polystyrene tray of 120 cells with one seed in each, for a total of 600 seeds per treatment. The percentage of germinated seeds and viable plantlets was evaluated, with seeds considered germinated when they reached the matchstick stage and plantlets considered viable when they contained a pair of true leaves fully expanded and no symptoms of necrosis or blister spot.

\section{Viability of seedlings}

Viable plantlets without symptoms were transplanted to $300 \mathrm{ml}$ disposable plastic cups with commercial sterilized substrate. The experimental design was a randomized block with three replicates, and the experimental plot was composed of 150 cups, with a seedling in each cup. The percentage of viable seedlings was evaluated, with those showing two pairs of fully expanded true leaves absent disease symptoms considered viable plants. 


\section{Obtaining isolates and pathogenicity test}

The necrotic parts of plantlets and seedlings with characteristic symptoms of the disease (items 2 and 3) were subjected to pathogen isolation to verify whether symptoms were related to Colletotrichum sp.

The infected tissues were decontaminated using 50\% alcohol for 30 seconds and $2 \%$ sodium hypochlorite for 2 minutes, rinsed in sterile distilled water twice, dried on sterile filter paper, and then transferred to a Petri dish containing culture media malt extract agar (2\% MEA) and maintained for seven days in a growth chamber at $25{ }^{\circ} \mathrm{C}$ with a 12 hour photoperiod. In total, three fungal isolates were obtained from lesions of Anthracnose and blister spot.

The pathogenicity of the fungal isolates was verified by re-inoculation of the genotype originated from diseased plants (GODP), which was submitted to a humidity chamber for 24 hours before and after inoculation with the pathogen. The inoculation sites were previously marked on the abaxial surface of the leaves using sticker discs with $1.4 \mathrm{~cm}$ diameter holes. Wounds were produced at these sites using a set of entomological needles to permit penetration and colonization of the fungus.

The inoculation was performed by depositing a $10 \mu \mathrm{L}$ drop of Colletotrichum sp. suspension $(2 \mathrm{x}$ $10^{6}$ conidia $\left.\mathrm{mL}^{-1}\right)$. Subsequently, the inoculated area was placed onto a permeable paper disk $(1.3 \mathrm{~cm}$ diameter) that had been previously moistened using sterile distilled water to form a micro-moist chamber (ABREU, 1988), and the disk was removed 48 hours after inoculation. For each cultivar, a seedling inoculated with sterile distilled water was used as a control.

The experimental design included randomized blocks with three replicates, and the experimental plot was composed of one plant. Disease severity was assessed 15 days after inoculation of the fungus using a rating scale adapted by Maia et al. (2013) (Table 1).

Table 1. Criteria for evaluation of the spectrum of coffee leaf reactions to Colletotrichum sp.

\begin{tabular}{cl}
\hline $\begin{array}{c}\text { Grade (degree } \\
\text { ofsymptoms) }\end{array}$ & Severity / Symptoms \\
\hline 0 & Absence of visual reaction \\
1 & Small and few (1 to 2) chlorotic or brownish lesions \\
2 & More than 2 brownish lesions or coalescent lesions. Lesion diameter exceeding $0.5 \mathrm{~mm}$ \\
3 & Extensive brownish lesions with numerous black points or dark lesions. Over 50\% coverage \\
4 & with lesions \\
\hline
\end{tabular}

Source: Maia et al. (2013).

The germination data, plantlet and seedling viability, and pathogenicity were analyzed using the Scott-Knott test at 5\% probability. Statistical analyses were performed using the statistical software Sisvar (FERREIRA, 2011).
Experiment II - Susceptibility to Colletotrichum sp. of seedlings originating from the seeds of plants with blister spot

\section{Obtaining coffee cultivars}

The seeds of cultivars Acaiá IAC 474-19, Araponga MG 1, Catiguá MG 2, Catuaí Vermelho IAC 144, Catucaí Amarelo 2 SL, Mundo Novo IAC 376-4, Paraíso MG H 419-1, Pau Brasil MG 
1, Sacramento MG 1 and Topázio MG 1190 were obtained from an experimental agricultural research farm (Empresa de Pesquisa Agropecuária de Minas Gerais - EPAMIG) in Três Pontas, Minas Gerais at the geographic coordinates $21^{\circ} 20^{\prime} 17.33^{\prime \prime} \mathrm{S}$ and $45^{\circ} 28^{\prime} 58.00^{\prime \prime}$ W. The cultivar Catuaí Vermelho IAC 144 (GODP) was obtained from plants with blister spot disease at the Laje Farm in Paraguaçu, Minas Gerais. Sowing was performed in polystyrene (Styrofoam) trays with 120 cells containing commercial sterilized substrate.

\section{Inoculation}

Plantlets were inoculated with the isolate MM1, which was identified as more aggressive in the pathogenic test in Experiment I. The seedlings in the stage known as "orelha de onça" were inoculated to assess the severity of Anthracnose in the cotyledon leaves, and inoculation was performed using the methodology described in item 3 of Experiment I.

\section{Evaluation of the disease and statistical analysis}

Disease severity was evaluated at 5, 10, 15 and 20 days after inoculation with Colletotrichum sp. using a rating scale described in Table 1.
The disease intensity index (DII) was determined using the following formula: $\mathrm{DII}=\sum(\mathrm{FxV}) /(\mathrm{NxX})$ $\mathrm{x} 100$, where $\mathrm{F}$ is the number of plants with a certain degree of symptoms; $\mathrm{V}$ is the degree of symptoms; $\mathrm{N}$ is the total number of inoculated plants and $\mathrm{X}$ is to the maximum degree of symptoms.

The area under the disease progress curve (AUDPC) was obtained based on the DII in accordance with Shaner and Finney (1977).

The experimental design was a randomized block with four replicates, and the experimental plot consisted of a seedling with two inoculated leaves. The severity data (DII) were analyzed using Tukey's test at 5\% probability. Statistical analyses were performed using the statistical software Sisvar (FERREIRA, 2011).

\section{Results and Discussion}

Experiment I - Seed germination and plantlet and seedling viability from the seeds of plants with blister spot symptoms

Significant differences were not observed in seed germination between the materials obtained from plants without blister spot symptoms and plants with blister spot symptoms (GODP); however, plantlet and seedling viability were significantly reduced in GODP plants by approximately $32 \%$ and $66 \%$, respectively (Table 2 ).

Table 2. Feasibility of propagation material from coffee plants with and without symptoms of blister spot.

\begin{tabular}{cccc}
\hline \multicolumn{1}{c}{ Treatments } & Seed Germination (\%) & Plantlet viability (\%) & Seedling viability (\%) \\
\hline presence of symptoms & $93,7^{*} \mathrm{a}$ & $64,9 \mathrm{~b}$ & $34.4 \mathrm{~b}$ \\
absence of symptoms & $95,3 \mathrm{a}$ & $95,3 \mathrm{a}$ & $100.0 \mathrm{a}$ \\
\hline
\end{tabular}

* Means followed by the same lowercase letter in the column are not significantly different according to the Scott-Knott test at 5\% probability. 
Ferreira et al. (2010) used a blotter test and did not observe significant differences in the germination of seeds from the two types of materials. However, after transplantation, the increased time of the evaluations indicated that a large number of dead plantlets had originated from seeds of plants with blister spot symptoms, and a linear trend was observed towards the increased incidence and severity of disease in diseased plantlets. In these plantlets, the authors initially observed superficial lesions that progressed into deeper and darker lesions that caused hypocotyl strangulation. Typical colonies of C. gloeosporioides were isolated from these lesions.

This study is the first to differentiate among the symptoms GODP plants reported in the literature beyond noting the symptoms of blister spot, which is characterized by a spot of bright green color that is less bright and has an oilier appearance that the sheet surface and measures between 2 and $10 \mathrm{~mm}$ in diameter (Figure 1D). Plantlets in the "orelha de onça" stage showed necrotic leaves and hypocotyls depressed by lesions characteristic of anthracnose (Figure 1C), which caused the death of many of the plantlets (Figure 1F). In seedlings with pairs of true leaves, we observed symptoms of anthracnose (Figure 1B) and blister spot (Figure 1D) as well as seedling wilt caused by an intense necrotic area in the stem (Figure 1E) and apical stem. This wilt may have been caused by the fungus colonizing conducting vessels for sap, and it has been observed by Lins et al. (2007) and Ferreira et al. (2009). Seedlings derived from plants without blister spot did not show any symptoms of the disease (Figure $1 \mathrm{G}$ and $1 \mathrm{H})$.
When these materials were submitted to a humidity chamber, pathogen sporulation was observed in necrotic lesions (Figure 2A), from which pure cultures of Colletotrichum sp. were obtained (Figure 2B) as confirmed by the conidia morphology (Figure 2C and 2D).

In the pathogenicity test of these isolates from plants, the isolate MM-1 was the most aggressive and caused anthracnose symptoms on the leaves, with yellow edges fully surrounding the leaf. Over time, the characteristic symptom of blister spot appeared on younger leaves that had not been inoculated (Figure 2E). At the end of the evaluations, the inoculated leaves were completely necrotic (Figure 2F), and senescence and wilting were observed, followed by the death of certain plants (Figure 2G). Seedlings inoculated with sterile distilled water showed no symptoms of the disease (Figure 2H).

Plants inoculated in the pathogenicity test were those that had survived the seedling feasibility test, which indicates that seemingly disease-free plants derived from the seeds of plants infected with blister spot are still infected by Colletotrichum sp., although they do not present symptoms of the disease prior to inoculation. Thus, this study confirms the hypothesis of Ferreira et al. (2010), which suggests that the surviving plantlets originating from seeds of trees with blister channel symptoms may produce new adult plants in the field that contribute to the spread of the disease. 
Figure 1. Main symptoms of blister spot observed in plantlets and seedlings originating from seeds of plants with symptoms of the disease.
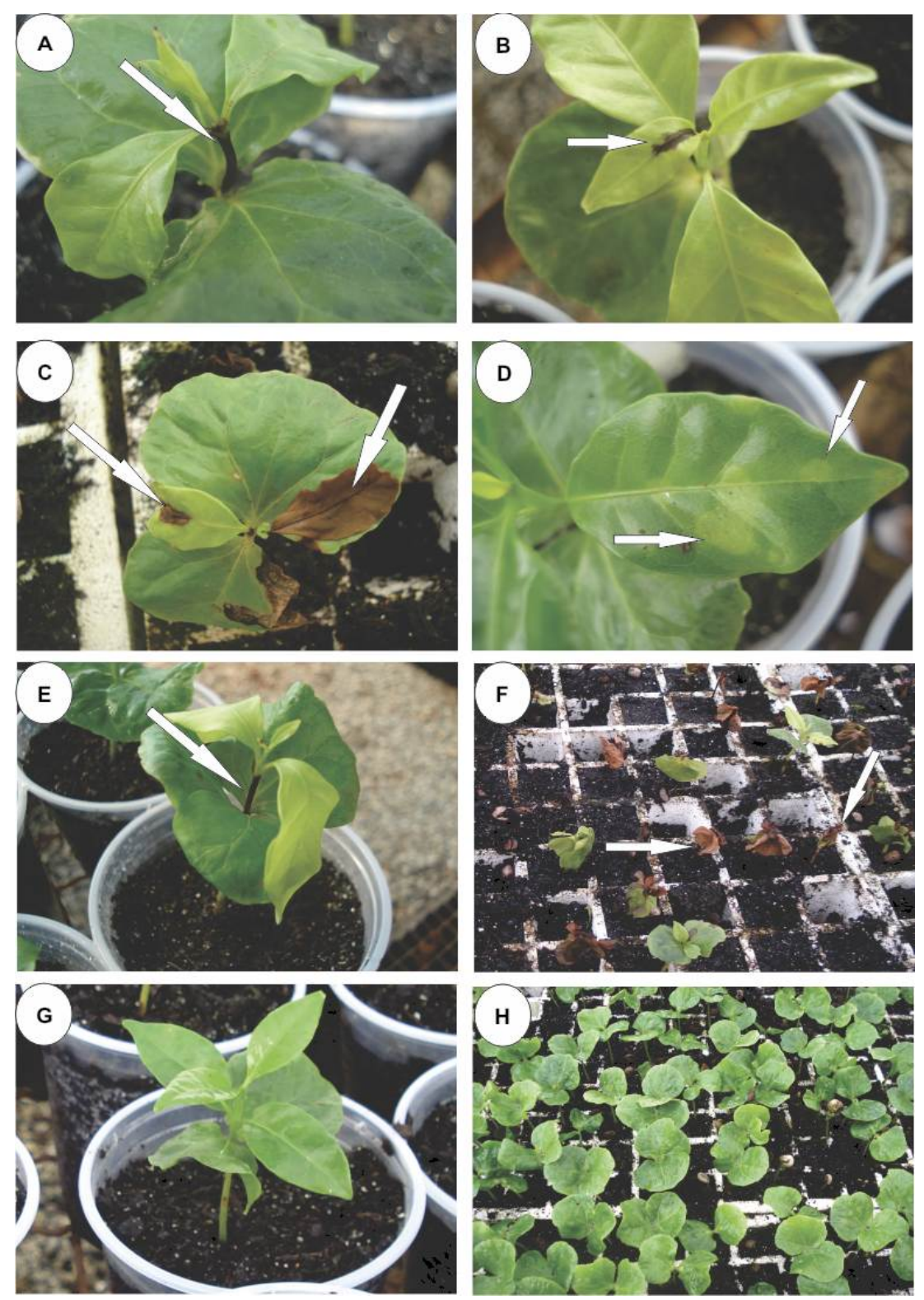

Note: A) Intense necrosis in the apical stem of seedlings. B) Appearance of necrotic spots on the upper leaves. C) Necrosis in the true leaves of the plantlets in the "orelha de onça," followed by death. D) True leaves showing the characteristic symptoms of blister spot. E) Stem necrosis and wilting of seedlings. F) Dead plantlets. ( $\mathrm{G}$ and H) Control: plants originating from seeds of healthy plants. 
Figure 2. Isolation, identification and pathogenicity of Colletotrichum sp. obtained from plants originating from coffee seeds with blister spot symptoms.
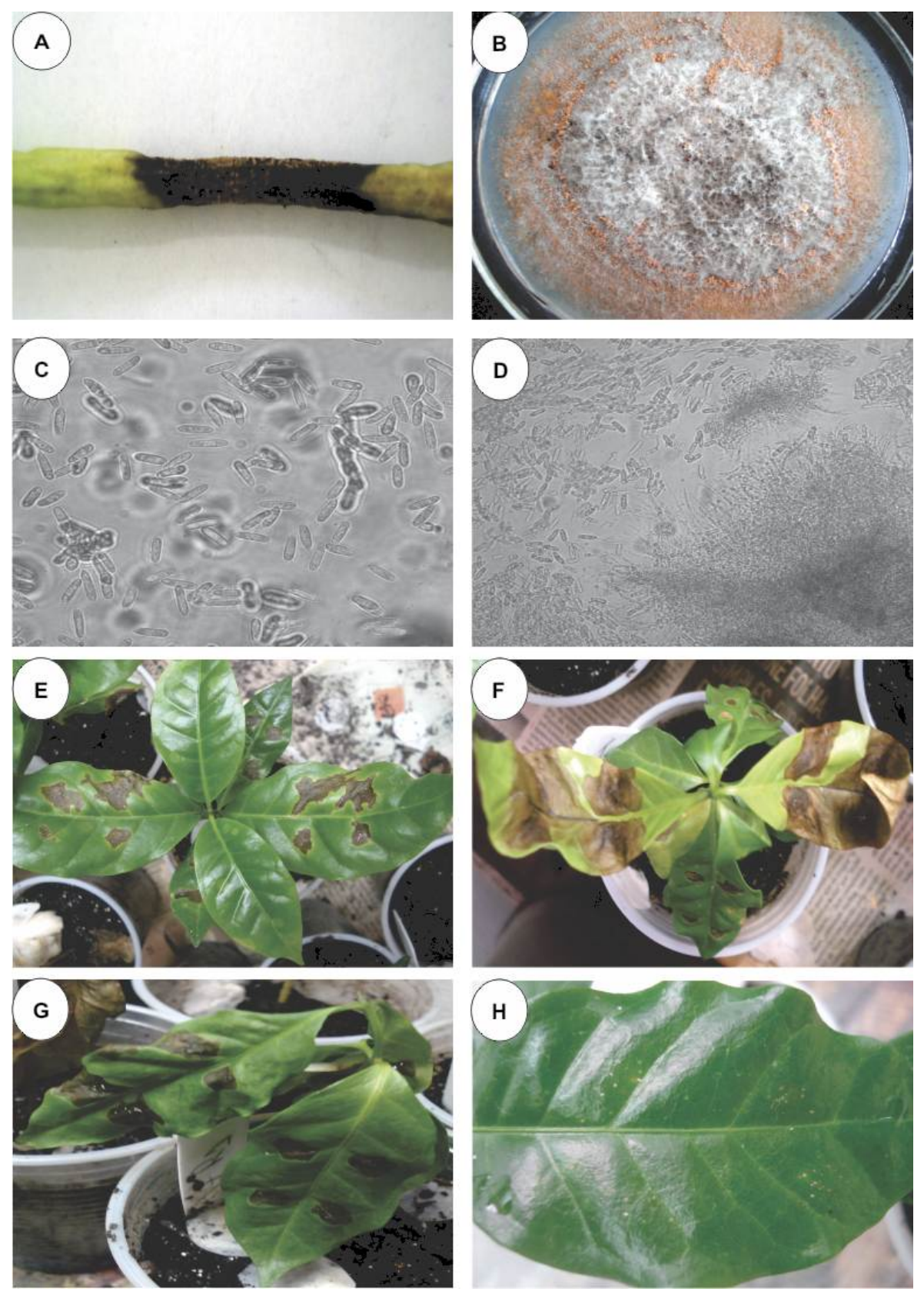

Note: A) Pathogen sporulation in injury after exposure to a moist chamber. B) Pure culture of Colletotrichum sp. in malt extract agar (2\%). (C and D) Characteristic conidia of Colletotrichum sp. E) Necrosis in the inoculated area and appearance of symptoms of blister spot in the upper leaves. F) Necrosis symptom progress until senescence in leaves. G) Intense necrotic area and wilting of seedlings. H) Control: coffee seedlings inoculated with sterile distilled water. 
Experiment II - Susceptibility to Colletotrichum sp. of seedlings originating from the seeds of plants with blister spot

The second experiment of this study verified that plantlets at the "orelha de onça" stage that were obtained from plants with blister spot (GODP) were more susceptible to Colletotrichum sp. compared with ten cultivars. Based on the AUDPC results, four groups were formed $(p<0.05)$ (Table 3$)$.
The Catuaí Vermelho IAC 144 cultivar was derived from plants with blister spot (GODP), and it was highly susceptible to the pathogen and had the highest AUDPC (Figures 3A and 3B). The cultivar Paraiso MG H 419-1 had the lowest AUDPC and was more resistant to anthracnose in cotyledon leaves (Figure 3D). Both Catuaí Vermelho IAC 144 and Acaiá IAC 474-19 showed similar reactions and were more susceptible than other cultivars.

Table 3. Anthracnose severity in different coffee cultivars.

\begin{tabular}{cc}
\hline Cultivars & Area Under Disease Progress Curve \\
\hline Paraíso MG H 419-1 & $404.3^{* *} \mathrm{a}$ \\
Pau Brasil MG 1 & $601.6 \mathrm{~b}$ \\
Catucaí Amarelo 2 SL & $609.4 \mathrm{~b}$ \\
Sacramento MG 1 & $611.3 \mathrm{~b}$ \\
Mundo Novo IAC 376-4 & $620.6 \mathrm{~b}$ \\
Catiguá MG 2 & $627.9 \mathrm{~b}$ \\
Araponga MG 1 & $628.9 \mathrm{~b}$ \\
Topázio MG 1190 & $630.4 \mathrm{~b}$ \\
Catuaí Vermelho IAC 144 & $689.5 \mathrm{c}$ \\
Acaiá IAC 474-19 & $708.9 \mathrm{c}$ \\
Catuaí Vermelho IAC 144 (GODP*) & $1453.1 \mathrm{~d}$ \\
\hline
\end{tabular}

* Genotype Originated of Diseased Plants (GODP): seedlings originating from the seeds of plants with blister spot. ** Means followed by the same lowercase letter in the column are not significantly different by the Scott-Knott test at 5\% probability.

The Catuaí Vermelho IAC 144 cultivar is used in several studies of this pathosystem as a standard susceptible cultivar because it is highly susceptible to the pathogen. Acaiá IAC 474-19 is derived from a selection of individual plants of the cultivar 'Mundo Novo' and susceptible to leaf rust, which indicates it can also be used as a standard susceptible cultivar in studies evaluating resistance to Colletotrichum sp. This is the first time the reaction of Acaiá IAC 47419 to inoculation with Colletotrichum sp. in leaves has been evaluated. However, this susceptibility was observed in the cultivar Acaiá Cerrado when the pathogen was inoculated in the hypocotyls (OROZCO-MIRANDA, 2003) and found to be present in exocarp and mesocarp of coffee fruits that were not inoculated with Colletotrichum sp. (FERREIRA et al., 2005).
The cultivar Paraíso MG H 419-1, which was more resistant in the present study, has a unique feature in its resistance to leaf rust derived from its artificial hybridization between Catuaí Amarelo IAC 30 and Timor Hybrid UFV 445-46. This resistance to both diseases may be derived from the species Coffea canephora Pierre ex A. Froehner because the Timor Hybrid arose from a natural cross between this species and Coffea arabica L.

Sera et al. (2005b) studied the reaction of $C$. arabica L. cultivars to Colletotrichum sp. in the field and found different levels of partial resistance to fruit necrosis associated with the presence of the pathogen, with resistance ranging from highly susceptible to moderately resistant. The authors concluded that segregation is occurring for fruit necrosis within cultivars and selections of the germplasm of Sarchimor, Catucaí, Icatu and Catuai. 
Figure 3. Anthracnose symptoms in coffee cultivars in response to inoculation with Colletotrichum sp. isolated from plants with symptoms of blister spot.
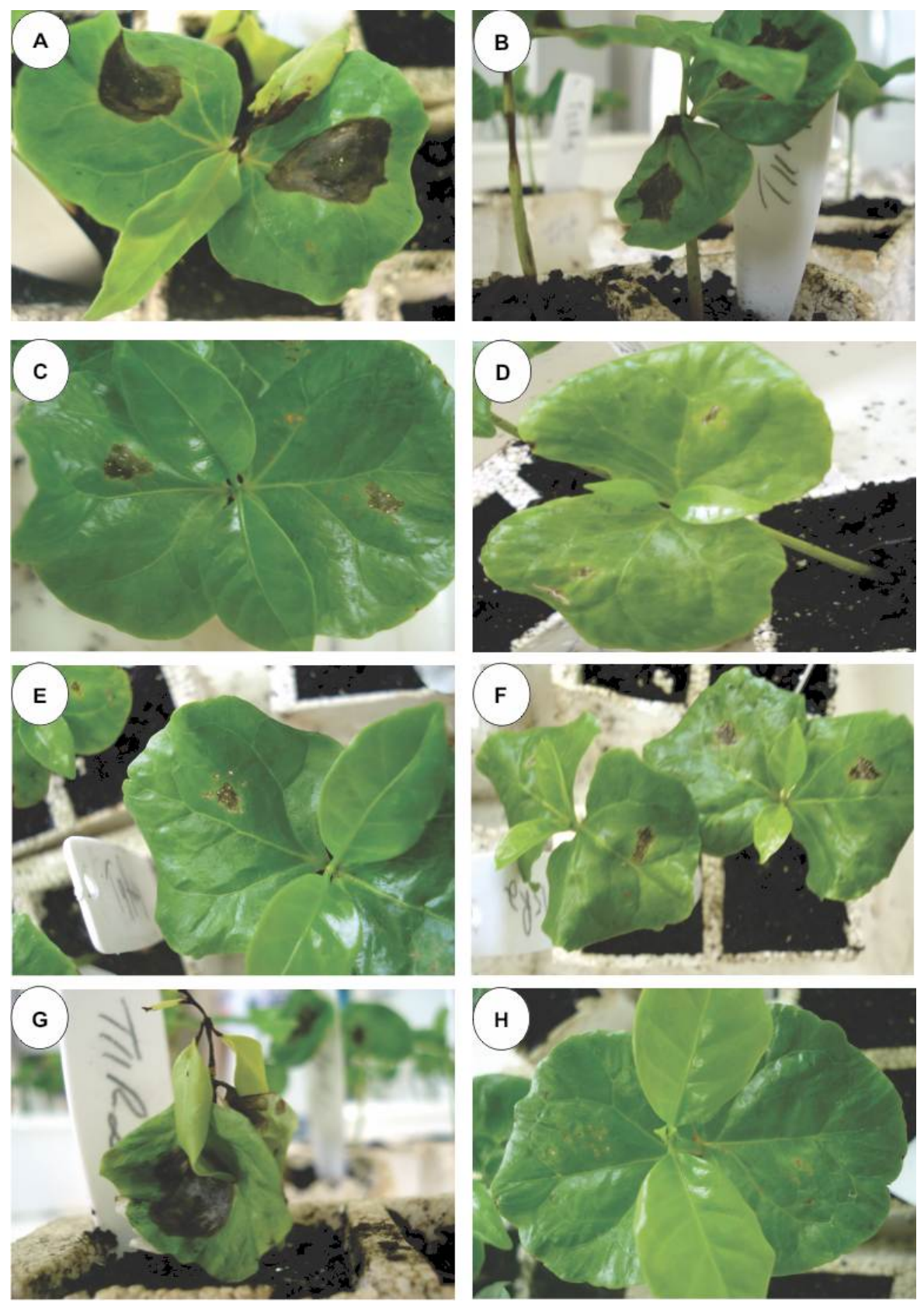

Note: (A and B) Seedling originating from seeds plants with symptoms of blister spot showing a strong necrotic area. C) Catiguá cultivar presenting intermediate resistance to the pathogen. D) Paraíso cultivar showing resistance. E) Catucaí Amarelo cultivar showing intermediate resistance. F) Catuaí Vermelho cultivar with a susceptibility pattern. G) Death of infected seedlings at the end of evaluations. H) Control: Catuaí Vermelho cultivar inoculated with sterile distilled water. 
Silva et al. (2011) evaluated the pathogenicity of C. gloeosporioides leaves of 13 different coffee varieties and observed fungus-induced depressed necrotic leaf spots of a dark brown color and noted the presence of conidial mass. Moreover, they observed that the average incidence of lesions on the seventh day after inoculation varied among the cultivars tested, with 97 asymptomatic cultivars, including IPR 97, IPR 98 and IPR 102, and a 56\% incidence for the cultivar IPR 100, which has been reported as the most susceptible. On the 14th day, the average incidence of lesions ranged from $6.25 \%$ in cultivar IPR 102 to $63 \%$ in cultivar IPR 100 .

Santos Neto (2012) evaluated the resistance of eight commercial cultivars of coffee to $C$. gloeosporioides in cotyledons inoculated with the pathogen. The author applied an AUDPC analysis and noted the formation of two groups that differed in terms of resistance. The first group was considered resistant and was used to cultivate Paraiso MG H 419-1, whereas the second group was considered susceptible and was used to cultivate Catuaí Vermelho IAC 144; the results of this study are consistent with those of the present work.

In this study, GODP plants were highly susceptible to the development of symptoms of anthracnose on the leaves in the first days after inoculation. Anthracnose symptoms were observed on leaves in all genotypes, and they only differed only in the AUDPC (Table 3) for severity of the disease, which indicates that the resistance of Arabica coffee genotypes to certain isolates of Colletotrichum sp. can be horizontal or polygenic because the resistance is characterized by lower disease severity in the evaluated materials (RIBEIRO et al., 1981). These types of resistance are sought after for plant breeding because of their greater stability and durability, and these qualities are the result of proximity to several genes with minor effects that are not specific to the pathogen races; therefore, the likelihood of the pathogen "breaking" the resistance is smaller compared with cultivars that exhibit vertical resistance (VAN DER PLANK, 1975).
Orozco-Miranda (2003) evaluated the hypocotyl resistance of twelve coffee cultivars in the Coffee Rust Research Center (CIFC), including two GODP plants and ten isolates of Colletotrichum sp. Only material from the GODP plants (Catucaí Amarelo and Catucaí Vermelho) were susceptible to the pathogen, and they showed a high mortality rate at the end of the evaluations. Only six of the ten isolates were pathogenic to both cultivars, including an isolate of Colletotrichum kahawae, indicating that there are compatible and incompatible interactions in this pathosystem. The authors concluded that plant material with stain blisters were more susceptible relative to other coffee germplasm, and such material presented disease symptoms only when inoculated with Colletotrichum sp. pathogens.

In this study, plantlet death in the final evaluations was only observed in GODP material, which indicates that these genotypes have a low resistance to blister spot and anthracnose on leaves. The symptoms of blister spot on leaves has always been related to necrosis. However, this is the first study that has evaluated the susceptibility of GODP cotyledons to anthracnose.

Thus, the results of this study indicate that GODP plants are susceptible to both blister spot and anthracnose, and additional studies should be performed on the pathosystem Colletotrichum $\mathrm{X}$ coffee to determine the factors responsible for susceptibility in these materials.

\section{Conclusions}

The feasibility of using propagative material from coffee seeds with blister spot (GODP) is lower relative to plants from other genotypes; however, germination was not affected. Furthermore, GODP species are more susceptible to Anthracnose on cotyledon leaves relative to the other commercial cultivars analyzed. 


\section{Acknowledgements}

The authors are grateful to the Federal University of Lavras (UFLA) and Department of Plant Pathology for the project development opportunity, the National Council for Scientific and Technological Development (CNPq) for granting a scholarship for this work, and the Minas Gerais State Research Foundation (FAPEMIG) for the financial resources to complete this project.

\section{References}

ABREU, M. S. Resistência horizontal a Hemileia vastatrix Berk \& Br. em cafeeiros descendentes do Híbrido de Timor. 1988. Tese (Doutorado em Fitopatologia) Universidade Federal de Viçosa, Viçosa, MG.

ABREU, M. S.; FERREIRA, J. B.; MARTINS, F. G. Mancha manteigosa no contexto do complexo Colletotrichum em cafeeiros. In: SIMPÓSIO DE MANEJODEPLANTAS: MANEJOFITOSSANITÁRIO DO CAFEEIRO, 8., 2008, Lavras. Anais... Lavras: UFLA, 2008. p. 105-126.

BRIDGE, P. D.; WALLER, J. M.; DAVIES, D.; BUDDIE, A. G. Variability of Colletotrichum kahawae in relation to other Colletotrichum species from tropical perennial crops and the development of diagnostic techniques. Journal of Phytopathology, Berlin, v. 156, n. 5, p. 274280, may 2008.

COMPANHIA NACIONAL DE ABASTECIMENTO - CONAB. Acompanhamento da safra brasileira de café: primeira estimativa. Brasília: CONAB, jan. 2014. Disponível em: <http:www.conab.gov.br $>$. Acesso em: 9 fev. 2014.

FERREIRA, D. F. Sisvar: a computer statistical analysis system. Ciência e Agrotecnologia, Lavras, v. 35, n. 6, p. 1039-1042, nov./dez. 2011.

FERREIRA, J. B. Aspectos histopatológicos, epidemiologia e controle da mancha manteigosa em Coffea arábica L. 2006. Tese (Doutorado em Fitopatologia) - Universidade Federal de Lavras, Lavras.

FERREIRA, J. B.; ABREU, M. S.; MACHADO, J. C.; PEREIRA, I. S.; FERNANDES, K. D. Transmissibilidade e efeito do tratamento de sementes de cafeeiros com mancha manteigosa (C. gloeosporioides). Ciência e Agrotecnologia, Lavras, v. 34, n. 1, p. 101-108, jan./fev. 2010.
FERREIRA, J. B.; ABREU, M. S.; PEREIRA, I. S. Análise da dinâmica, estrutura de focos e arranjo espacial da mancha manteigosa em campo. Ciência e Agrotecnologia, Lavras, v. 33, n. 1, p. 24-30, jan./fev. 2009.

Incidência de Colletotrichum spp. em frutos de Coffea arabica L. em diferentes estádios fisiológicos e tecidos do fruto maduro. Ciência e Agrotecnologia, Lavras, v. 29, n. 4, p. 880-885, jul./ago. 2005.

LINS, S. R. O.; ABREU, M. S.; ALVES, E. Estudos histopatológicos de Colletotrichum spp. em plântulas de cafeeiro. Fitopatologia Brasileira, Brasília, v. 32, n. 6, p. 488-495, 2007.

MAIA, F. G. M.; ARMESTO, C.; OGOSHI, C.; VIEIRA, J. F.; MAIA, J. B.; ABREU, M. S. Comportamento de isolados de Colletotrichum gloeosporioides inoculados em mudas micropropagadas de café. Bioscience Journal, Uberlândia, v. 29, n. 6, p. 1896-1904, nov./dez. 2013.

MANSK, Z.; MATIELLO, J. B. Ocorrência de mancha manteigosa em café "Conilon" (Coffea canephora, Pierre) no Estado do Espírito Santo. In: CONGRESSO BRASILEIRO DE PESQUISAS CAFEEIRAS, 5., 1977, Guarapari. Anais... Guarapari: IBC/GERCA, 1977. p. 172-173.

MARQUES, V. V. Patogenicidade e variabilidade genética de Colletotrichum spp. em cafeeiro (Coffea arabica L.). 2009. Tese (Doutorado em Agronomia) Universidade Estadual de Londrina, Londrina.

NGUYEN, T. H. P.; SÄLL, T.; BRYNGELSSON, T.; LILJEROTH, E. Variation among Colletotrichum gloeosporioides isolates from infected coffee berries at different locations in Vietnam. Plant Pathology, Oxford, v. 58, n. 5, p. 898-909, oct. 2009.

OROZCO-MIRANDA, E. F. Caracterização morfológica, molecular, bioquímica e patogênica de isolados de Colletotrichum spp. associados ao cafeeiro em Minas Gerais e comparação com Colletotrichum kahawae. 2003. Tese (Doutorado em Fitopatologia) Universidade Federal de Lavras, Lavras.

PARADELA FILHO, O.; PARADELA, A. L.; THOMAZIELLO, R. A.; RIBEIRO, I. J. A.; SUGIMORI, M. H.; FAZUOLI, L. C. O complexo Colletotrichum do cafeeiro. Campinas: IAC, 2001. 11 p. (Boletim técnico IAC, 191).

PEREIRA, I. S.; ABREU, M. S.; ALVES, E.; FERREIRA, J. B. Estudos histopatológicos da interação Colletotrichum gloeosporioides: cafeeiro. Bragantia, Campinas, v. 68, n. 1, p. 117-123, out. 2009. 
RIBEIRO, I. J. A.; BERGAMIM FILHO, A.; CARVALHO, P. C. T. Avaliação da resistência horizontal a Hemileia vastatrix Berk et Br. em cultivares de Coffea arabica $\mathrm{L}$. em condições naturais de epidemia. Summa Phytopathologica, Piracicaba, v. 7, n. 1-2, p. 80-95, 1981.

SANTOS NETO, H. Resistência em cafeeiro a Colletotrichum gloeosporioides, isolado da mancha manteigosa. 2012. Dissertação (Mestrado em Fitopatologia) - Universidade Federal de Lavras, Lavras.

SERA, G. H.; ALTÉIA, M. Z.; SERA, T.; PETEK, M. R.; ITO, D. S. Correlação entre a ocorrência de Colletotrichum spp. e outras características agronômicas em cafeeiros. Bragantia, Campinas, v. 64, n. 3, p. 435440, 2005a.

SERA, G. H.; SERA, T.; ITO, D. S.; AZEVEDO, J. A.; RIBEIRO FILHO, C. de; PETEK, M. R.; MATA, J. S. da; DOI, D. S.; COTARELLI, V. M. Resistência de campo ao Colletotrichum spp. entre genótipos de café (Coffea arabica L.). In: SIMPÓSIO DE PESQUISA DOS CAFÉS DO BRASIL, 4., 2005, Londrina. Anais... Brasília, DF: Embrapa Café, 2005b. CD-ROM.
SHANER, G.; FINNEY, R. E. The effect of nitrogen fertilization on the expression of slow-mildewing resistance in Knox wheat. Phytopathology, Saint Paul, v. 67, n. 8, p. 1051-1056, aug. 1977.

SILVA, D. A. de; BARBOZA, A. A. L.; MARQUES, V. V.; SILVA, M. R. L. da; LEITE JUNIOR, R. P. Patogenicidade de Colletotrichum gloeosporioides em folhas de cafeeiro. In: SIMPÓSIO DE PESQUISA DOS CAFÉS DO BRASIL, 7., 2011, Araxá. Anais... Brasília: Embrapa Café, 2011.

SILVA, D. N.; TALHINAS, P.; CAI, L.; MANUEL, L.; GICHURU, E.K.; LOUREIRO, A.; VÁRZEA, V.; PAULO, O. S.; BATISTA, D. Host-jump drives rapid and recent ecological speciation of the emergent fungal pathogen Colletotrichum kahawae. Molecular Ecology, Weinheim, v. 21, n. 11, p. 2655-2670, jun. 2012.

VAN DER PLANK, J. E. Principles of plant infection. New York: Academic, 1975. 216 p.

VARGAS, G. E.; GONZALEZ, U. L. C. La mancha mantecosa del café causada por Colletotrichum spp. Turrialba, San José, v. 22, n. 2, p. 129-135, abr./jun. 1972. 
